\title{
OPEN Author Correction: A global mass budget for positively buoyant macroplastic debris in the ocean
}

Laurent Lebreton, Matthias Eggeri(i) \& Boyan Slat

Correction to: Scientific Reports https://doi.org/10.1038/s41598-019-49413-5, published online 12 September 2019

This Article contains errors.

The Competing Interests section in this Article is incorrect and should read:

"The authors are employed by The Ocean Cleanup, a non-for-profit organization that develops technology to rid the oceans of plastic."

In addition, the text for several equations is incorrect; Equation 6,

“ $\mathrm{C}_{\mathrm{m}}\left(\mathrm{y}, \mathrm{y}_{0}\right)=\left(1+\mathrm{d}_{\mathrm{C}}\right) * \mathrm{C}_{\mathrm{M}}\left(\mathrm{y}-1, \mathrm{y}_{0}\right) "$

should read:

“ $\mathrm{C}_{\mathrm{m}}\left(\mathrm{y}, \mathrm{y}_{0}\right)=\mathrm{C}_{\mathrm{m}}\left(\mathrm{y}-1, \mathrm{y}_{0}\right)+\mathrm{d}_{\mathrm{C}} * \mathrm{C}_{\mathrm{M}}\left(\mathrm{y}-1, \mathrm{y}_{0}\right)$ "

The text for Equation 7,

" $\mathrm{S}_{\mathrm{m}}\left(\mathrm{y}, \mathrm{y}_{0}\right)=\left(1+\mathrm{d}_{\mathrm{S}}\right) * \mathrm{~S}_{\mathrm{M}}\left(\mathrm{y}-1, \mathrm{y}_{0}\right) "$

should read:

" $\mathrm{S}_{\mathrm{m}}\left(\mathrm{y}, \mathrm{y}_{0}\right)=\mathrm{S}_{\mathrm{m}}\left(\mathrm{y}-1, \mathrm{y}_{0}\right)+\mathrm{d}_{\mathrm{S}} * \mathrm{~S}_{\mathrm{M}}\left(\mathrm{y}-1, \mathrm{y}_{0}\right) "$

The text for Equation 8,

“ $\mathrm{O}_{\mathrm{m}}\left(\mathrm{y}, \mathrm{y}_{0}\right)=\left(1+\mathrm{d}_{\mathrm{O}}\right) * \mathrm{O}_{\mathrm{M}}\left(\mathrm{y}-1, \mathrm{y}_{0}\right) "$

should read:

“ $\mathrm{O}_{\mathrm{m}}\left(\mathrm{y}, \mathrm{y}_{0}\right)=\mathrm{O}_{\mathrm{m}}\left(\mathrm{y}-1, \mathrm{y}_{0}\right)+\mathrm{d}_{\mathrm{O}} * \mathrm{O}_{\mathrm{M}}\left(\mathrm{y}-1, \mathrm{y}_{0}\right) "$

(c) (i) Open Access This article is licensed under a Creative Commons Attribution 4.0 International Cicense, which permits use, sharing, adaptation, distribution and reproduction in any medium or format, as long as you give appropriate credit to the original author(s) and the source, provide a link to the Creative Commons license, and indicate if changes were made. The images or other third party material in this article are included in the article's Creative Commons license, unless indicated otherwise in a credit line to the material. If material is not included in the article's Creative Commons license and your intended use is not permitted by statutory regulation or exceeds the permitted use, you will need to obtain permission directly from the copyright holder. To view a copy of this license, visit http://creativecommons.org/licenses/by/4.0/.

(c) The Author(s) 2020 